\title{
Memories of migration? The 'Anglo-Saxon' burial costume of the fifth century AD
}

\author{
James M. Harland
}

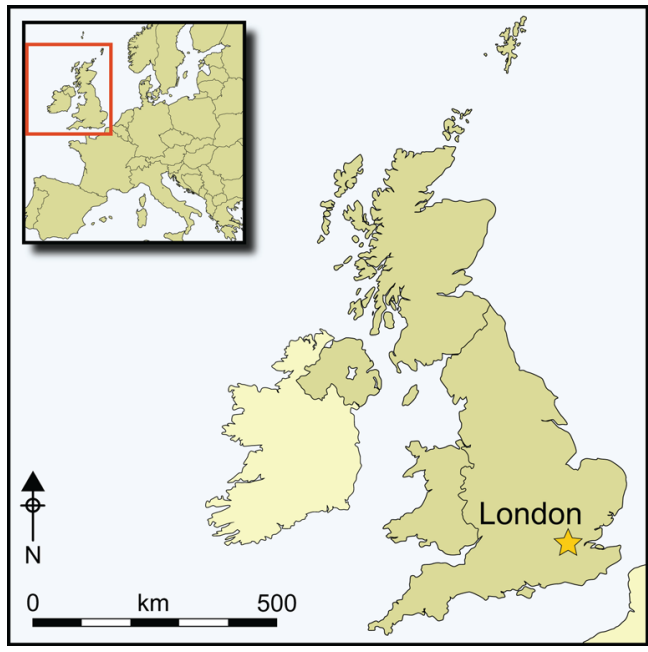

It is often claimed that the mortuary traditions that appeared in lowland Britain in the fifth century $A D$ are an expression of new forms of ethnic identity, based on the putative memorialisation of a 'Germanic' heritage. This article considers the empirical basis for this assertion and evaluates it in the light of previously proposed ethnic constructivist approaches. No sound basis for such claims is identified, and the article calls for the development of new interpretative approaches for the study of early medieval mortuary archaeology in Britain.

Keywords: Britain, Anglo-Saxon, ethnicity, migration, mortuary archaeology

\section{Introduction}

Ethnic identity is a situational construct that fashions communities through real and fictive stories and memories. Studies of early Anglo-Saxon burial archaeology have long recognised this, and scepticism regarding the putatively 'Germanic' culture of some graves in England can be found as early as Hills (1979). Such early doubts, however, depended largely upon the absence of evidence for 'Germanic' material culture, rather than a questioning of the ethnic categories proposed. The arguments for the interpretation of this material culture derive largely from studies of 'Germanic' material on the European continent - to which British scholarship sometimes makes unquestioning reference, and most works published before 2000 simply adopted a constructivist approach to culture-historical interpretation. These works introduced the notion that ethnic identity is a situational construct, rather than a static

* Eberhard Karls Universität Tübingen, DFG Center for Advanced Studies 2496 Migration and Mobility in Late Antiquity and the Early Middle Ages', Keplerstraße 2, Tübingen 72074, Germany (Email: james.harland@philosophie.uni-tuebingen.de)

(C) Antiquity Publications Ltd, 2019. This is an Open Access article, distributed under the terms of the Creative Commons Attribution licence (http://creativecommons.org/licenses/by/4.0/), which permits unrestricted re-use, distribution, and reproduction in any medium, provided the original work is properly cited.

ANTIQUITY 93370 (2019): 954-969

https://doi.org/10.15184/aqy.2019.60 
essentialist entity; but the assumption that the particular identities that were studied were largely direct imports from the continent remained unchanged (e.g. Hines 1984; Härke 1990; for an exception, see Pader 1982; for overviews of the discipline's development, see Lucy 2000; Hills 2003). The important criticisms of Lucy (1998, 2000, 2002), in particular, warn against this simplistic culture-historical approach to the interpretation of the material culture of fifth-century AD Britain.

Subsequent research has significantly changed our understanding of the mechanisms whereby people came across the North Sea from Germania Magna and Scandinavia in the fourth to sixth centuries $\mathrm{AD}$ to settle in Britain, bringing with them new forms of material culture. These studies reject the notion that the new material culture associated with these migrations passively reflects the importation of static, distinct and fixed ethnic groups. They instead propose that this new material culture was used by the communities of early medieval Britain (and the former Western Roman Empire) to construct new ethnicities, using real and imagined memories of migration and allusions to 'Germanic' cultural myths-as later recorded by the eighth-century historian Bede under the names 'Angle', 'Saxon' and 'Jute' (Colgrave \& Mynors 1969; Hakenbeck 2011; Gerrard 2013; Hills 2015; Martin 2015). Martin (2015), for example, uses his cruciform brooch typology to argue that the new styles of decoration in the fifth century functioned as tradition-bearing material culture. The allusions to 'Germanic' myth and the real or fictive memories of migration evoked by this material were then used to construct a new 'Anglian' ethnicity out of the diverse peoples who migrated to what would become Northumbria and East Anglia. Martin (2015) invokes a classic argument originating from scholars of medieval history (Wenskus 1961; Wolfram 1979; for criticism, see Gillett 2002) about early medieval ethnic identity as being based around 'tradition-bearing' elites.

The brief reports thus far published on the recent excavations at Scremby in Lincolnshire, which describe a single buckle as being "commonly associated with Jutish communities in Kent" (University of Sheffield 2018), might be considered indicative of the dominance of this approach, but can it reasonably be advocated? This is not simply one interpretative option presented among others; it has become far more pervasive than the available empirical evidence reasonably allows. Constructivist approaches to ethnicity raise a considerable epistemological barrier to those who would seek to identify it in the archaeological record, yet such difficulties are rarely heeded by those who espouse constructivist ideals. Ethnic sociology recognises this as a wider problem. Brubaker (2004: 3), for example, observes that

it is not that the notion of social construction is wrong; it is rather that it is today too obviously right, too familiar, too readily taken for granted, to generate the friction, force, and freshness needed to push arguments further and generate new insights. One symptom of this intellectual slackness is that one often finds constructivist and groupist language casually conjoined.

Although patterned social phenomena can, in some instances, be identified as expressions of ethnicity, this situation cannot be universalised. The construction of ethnic boundaries is highly context-dependent, and requires case-by-case analysis. The only universal characteristic of ethnicity is that it emerges from the coding and framing of acts as 'ethnic' (Brubaker

(C) Antiquity Publications Ltd, 2019 
2004; Wimmer 2013). The etic observer who turns first to ethnicity for the interpretation of patterns in material culture reifies ethnic expression—an emic phenomenon-without empirical basis. Apparently similar patterns of human phenomena cannot be assumed universally to represent expressions of ethnicity without empirical basis (Wimmer 2013). This article demonstrates that we lack a sound basis for the assumption that early Anglo-Saxon burial costume expresses ethnicity. Such an absence will be shown through consideration of two aspects of material culture that are usually held —erroneously—-to form the empirical basis for such interpretations. First, I consider artistic styles of early medieval metalwork, which are claimed to evidence adherence to 'Germanic' religious beliefs and origin myths (see below). I then consider a female-gendered style of dress, which this metalwork was used to fasten, and which is claimed to represent a form of ethnic 'folk costume' (or Tracht, see below).

\section{The 'breath of Odin'? Zoomorphic art styles}

A series of chip-carved decorative styles from North-western Europe are central to the argument that early Anglo-Saxon burial costume evoked a 'pan-Germanic' cultural ethos. These styles are usually known as 'Nydam Style', 'Saxon Relief Style' and 'Style I', and originated in Scandinavia and northern Germany in the late fourth to fifth, mid and late fifth centuries AD, respectively (Haseloff 1981; Inker 2006; Webster 2009). Although they are distributed across Scandinavia, lowland Britain and North-western continental Europe, the styles have very different chronologies across these regions (Høilund Nielsen 2012).

It has long been known that these styles descend from chip-carved decorative styles on Roman military metalwork from the Rhine and Danube (Figures 1-2), and took on new characteristics following their adoption in Germania and Scandinavia (Haseloff 1974, 1981). Early attempts to explain the spread of chip-carved styles to Germania hypothesised that Roman craftsmen must have been kidnapped by the societies beyond the Rhine (Haseloff 1974); this hypothesis now finds little scholarly credence (Inker 2006).

This art is immensely varied, as is the metalwork, ranging from a hugely diverse range of belt buckle styles, to great square-headed brooches (Figure 3), smaller saucer or applied brooches (Figure 4) and the cruciform brooches upon which Martin (2015) bases his ethnic interpretation (Figure 5). These are usually considered to be emblematically 'Germanic', and in a similar manner to the art depicted on Scandinavian bracteates descended from Roman imperial solidi, to which they bear close formal relation (Behr 2000; Dickinson 2002; Martin 2015). Even when attempts are made to problematise the way in which ethnicity is inferred from this material, the adoption of these new art styles is still often assumed to indicate the transition towards a 'Germanic ideology' (e.g. Gerrard 2013). When such views are not based on culture-historical reasoning, this Germanic 'essence' is presumed to have come from the metalwork's role in conveying cosmologies and ideologies that refer to the 'Germanic' world, such as pagan myths or migration narratives preserved in Late Roman texts. These cosmological frameworks supposedly provide a cultural coherence that lends these decorative styles their 'Germanic' quality (Behr 2000, 2007; Hedeager 2000, 2011; Behr \& Pestell 2014: 68; Martin 2015: 154-55; Pesch 2017). While there are countless examples of this line of argument, Hedeager (2000: 3738; also argued with little alteration in Hedeager 2011: 37-41, 50-58) is fairly typical and widely cited; her understanding is based upon the assumption that material symbolism is an

(C) Antiquity Publications Ltd, 2019 

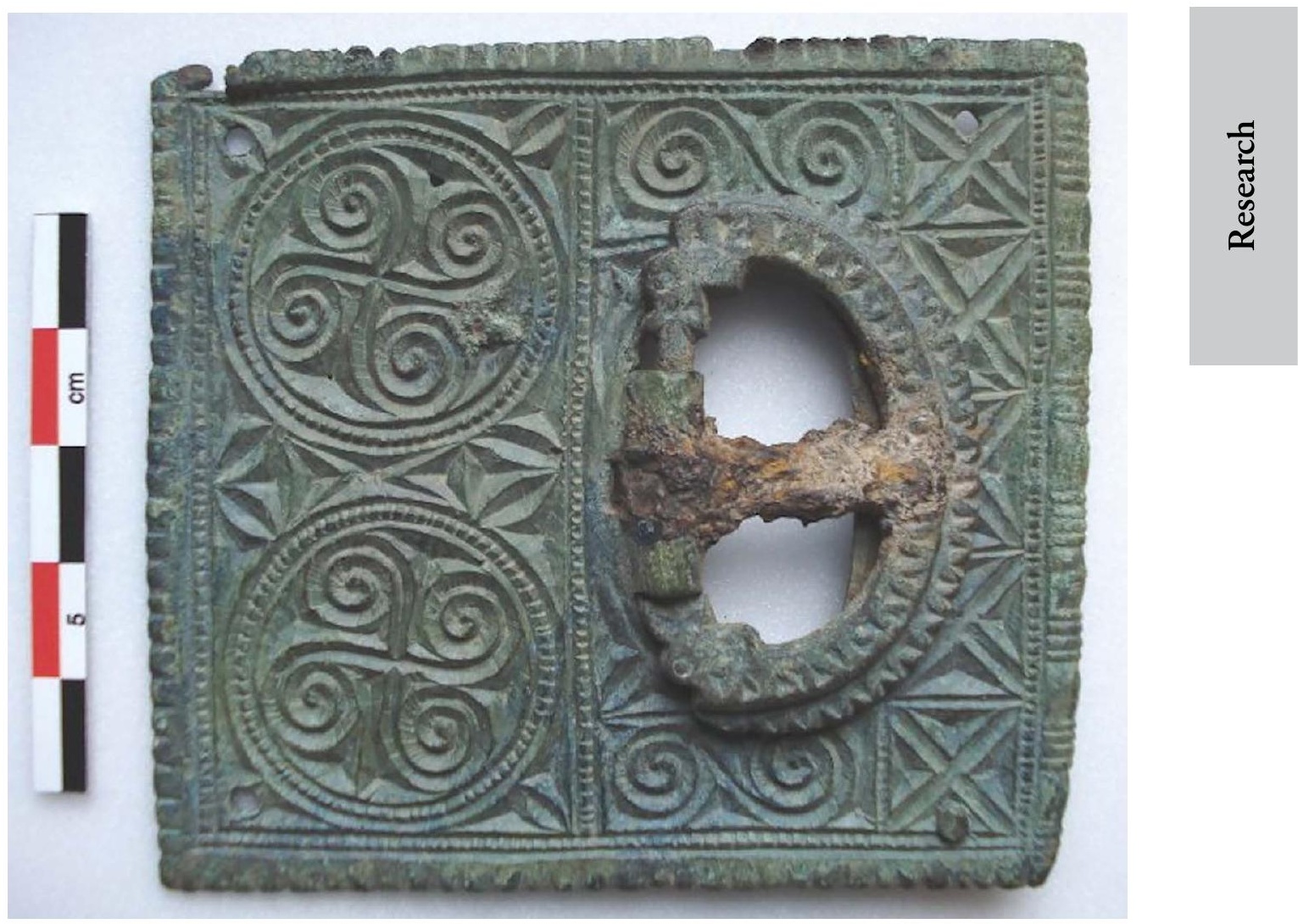

Figure 1. Belt buckle from the Late Roman cemetery at the Liebfrauenkirche, Worms. An example of provincial Roman chip-carved military metalwork (photograph courtesy of The British Museum).

act of expression for the signalling of identity, providing a methodological bridge for material culture to be interpreted through the use of the textual evidence.

Although such a premise is reasonable, there is no evidence for a body of coherent pagan myths that represent the proposed medium by which fifth-century identity was signalled, or-if these myths existed at all—that their coherence was recognised at that time. The cosmological beliefs that would have functioned to express these identities-if these are what this art even conveyed-are unknown and unknowable. Interestingly, Hedeager (2000) accepts that her proposal that early animal art may have conveyed mythological meaning is unverifiable, but this admission is not extended to the resulting notion that these decorative styles, and the metalwork on which they featured, could be associated with 'Germanic' peoples. Moreover, to support such claims, Hedeager argues that continental Germani collectively shared Scandinavian origin myths: "Germanic peoples on the continent and in England will have had an understanding of the depictions on the bracteates and the brooches" (Hedeager 2000: 43). But this assumes that there is something intrinsic to the "Germanic ethos' that enabled its participants to interpret these brooches, when others (such as citizens of the Roman Empire) could not. Moreover, this assumption derives entirely from empirically non-verifiable assertions that these items exhibited iconography that in turn conveyed to

(C) Antiquity Publications Ltd, 2019 


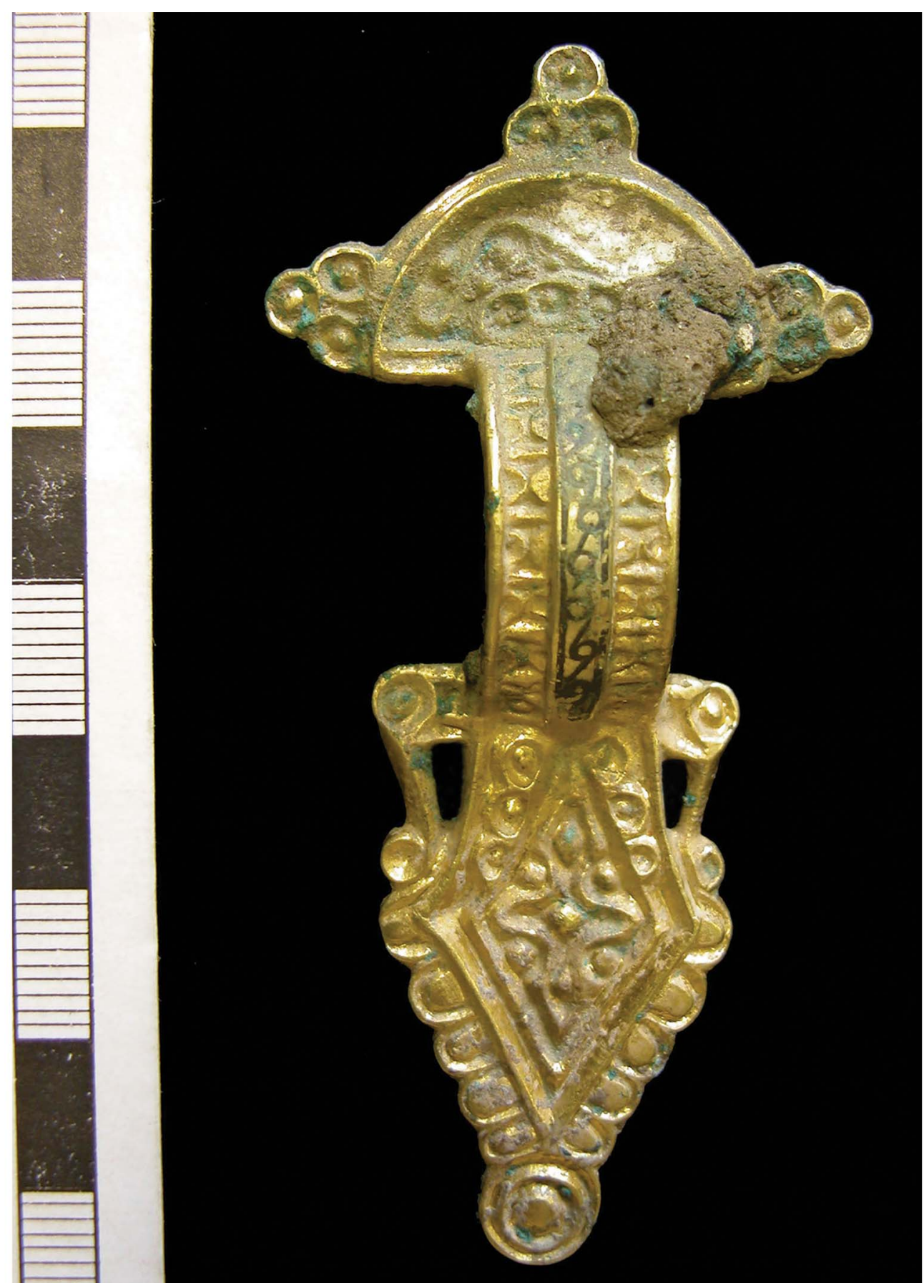

Figure 2. Nydam-style chip-carved decoration on a brooch from Kent. These brooch types originate in Scandinavia, but show clear Roman stylistic influence (early fifth century AD, scale in centimetres, brooch is approximately $80 \mathrm{~mm}$ in length; photograph courtesy of The Portable Antiquities Scheme).

(C) Antiquity Publications Ltd, 2019 


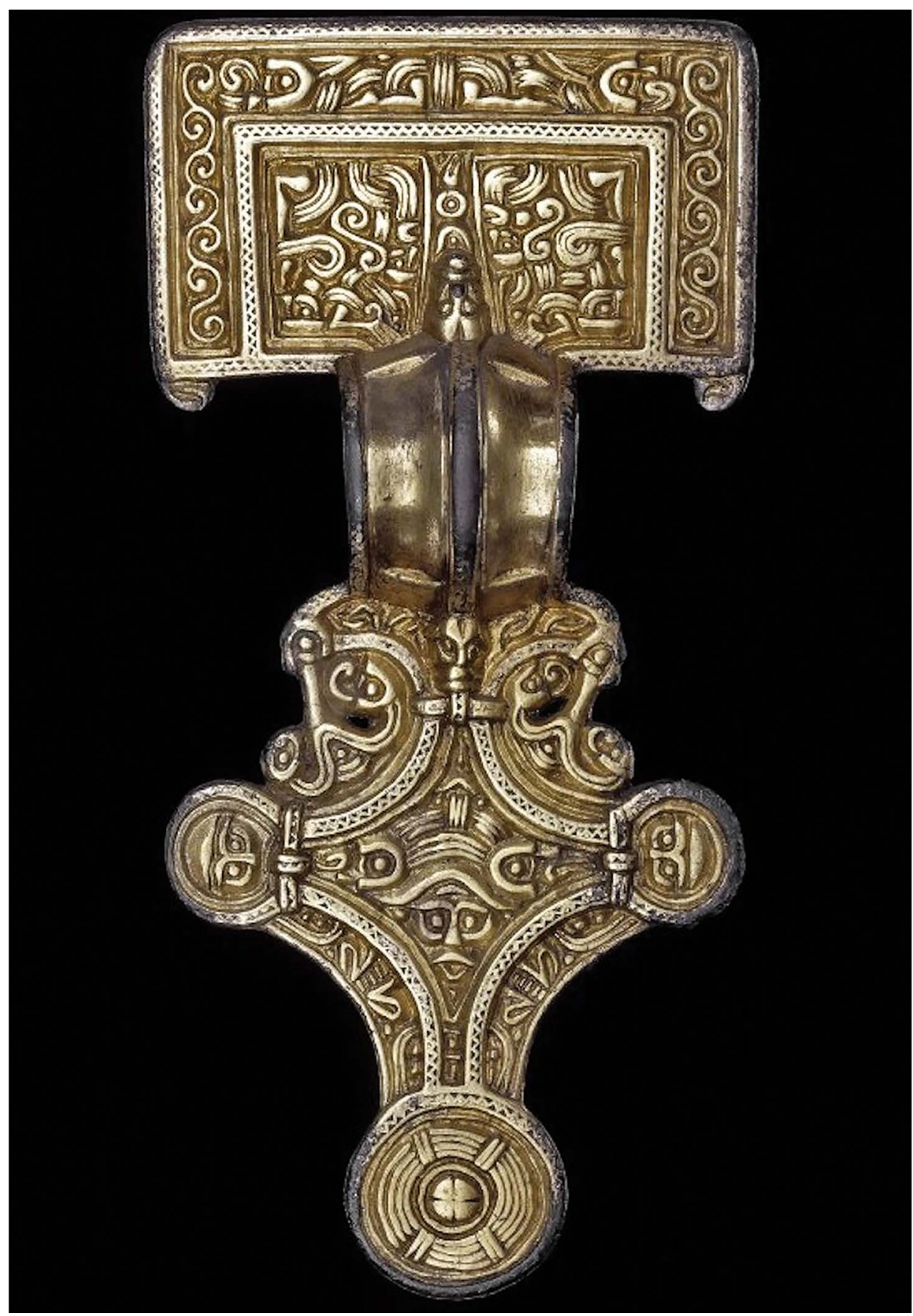

Figure 3. Great square-headed brooch with Style I decoration from Chessell Down, Isle of Wight (late fifth century AD, no scale was provided in the original version of this figure; photograph courtesy of The British Museum). 


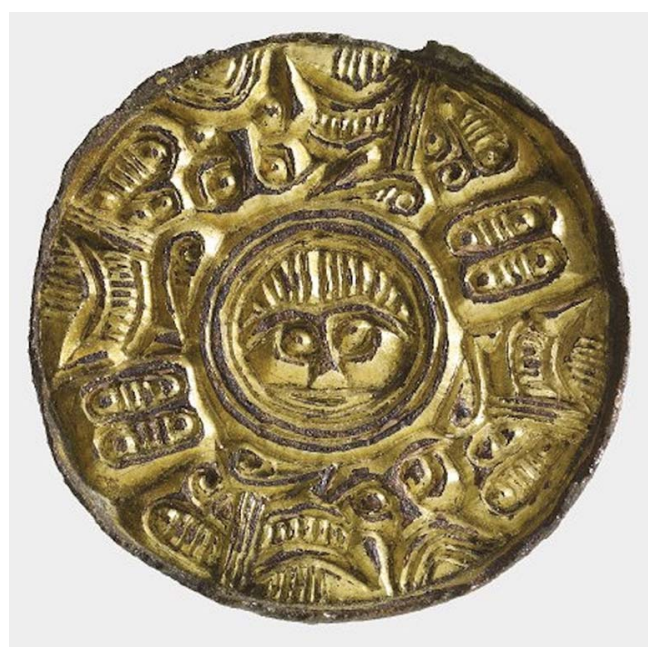

Figure 4. Saucer brooch with Style I decoration from Aston, Berkshire (no scale was provided in the original version of this figure; photograph courtesy of The British Museum). their users the later Nordic myths, which have been preserved in high medieval Icelandic eddaic literature.

A similar set of assumptions also allows Inker (2006) to ascribe a 'Germanic' significance to the Saxon Relief Style. This style is found mostly on applied and cast saucer brooches (Figure 6), which originate in regions described by proponents of culturehistorical interpretation as 'Saxon' (e.g. Leeds 1912: 160). This style likewise developed through the adoption and adaptation in Germania of zoomorphic styles originally found on the provincial Roman military frontier (Haseloff 1974, 1981; Inker 2006). Inker criticises attempts by earlier students of Saxon Relief Style, because of these origins, to downplay its

'Germanic' aspects. Inker suggests instead that this style's creation was an expression of the identification of Germanic peoples with the martial prowess of the Roman army, asserting that this "was set in train by the growth of warrior status of gods and leaders in north European peoples during the Later Roman Iron Age” (Inker 2006: 2). For Inker (2006: 1),
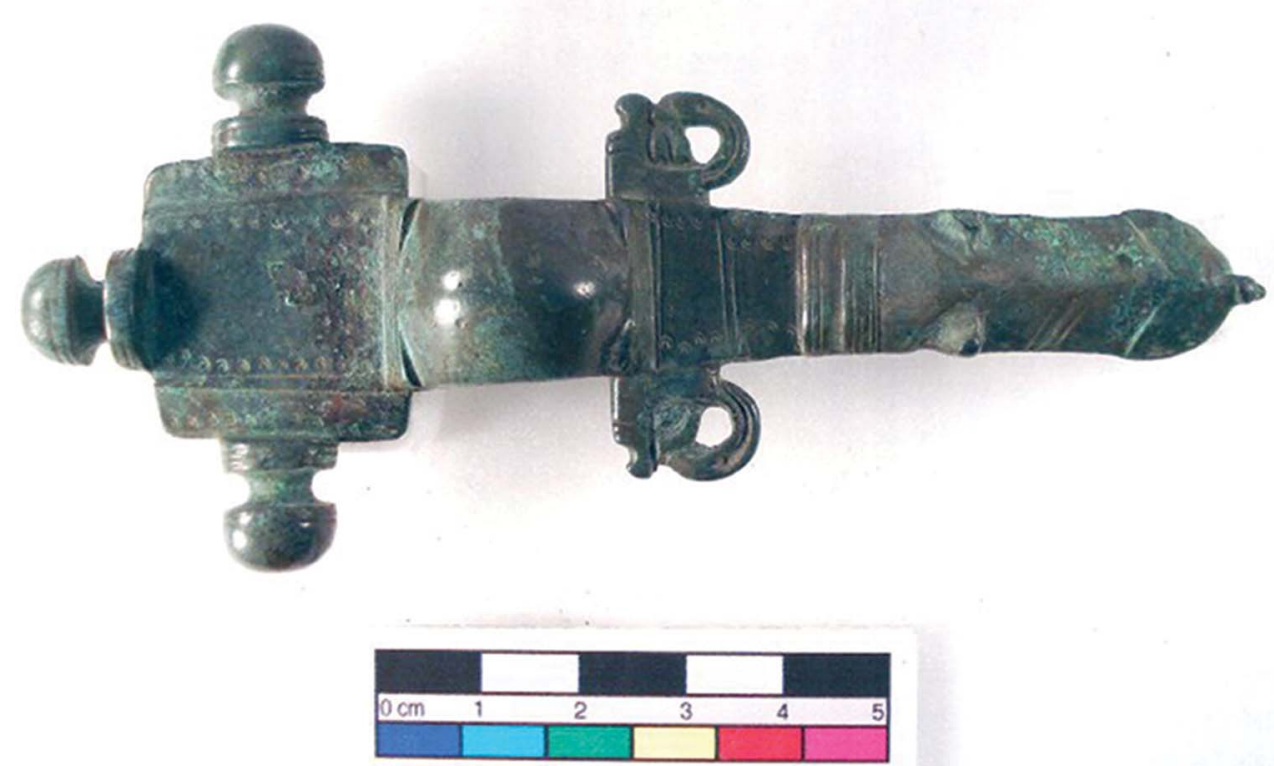

Figure 5. Cruciform brooch with a Style I animal-head terminal and bird-head lappets, Lakenheath, Suffolk (late fifth) early sixth century AD; photograph courtesy of The British Museum).

(C) Antiquity Publications Ltd, 2019 

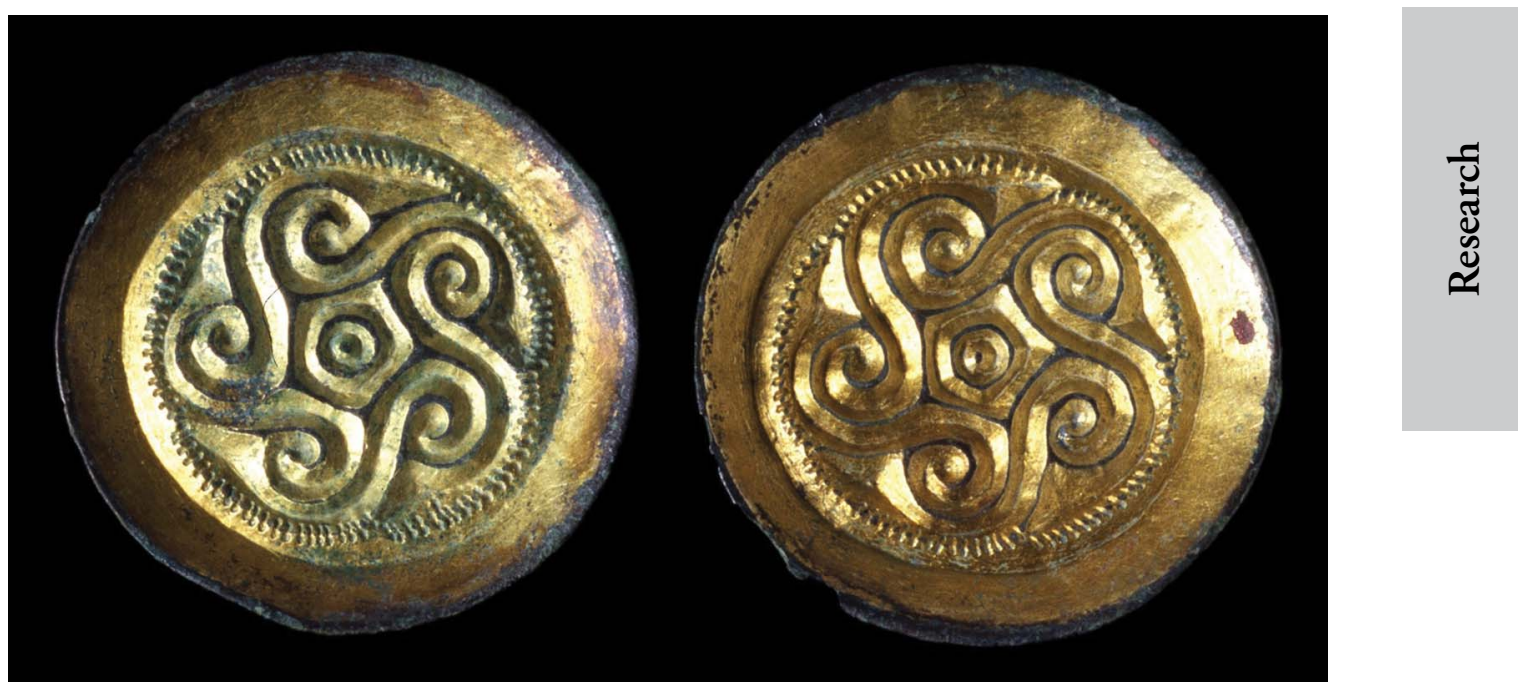

Figure 6. Pair of saucer brooches with Saxon Relief Style spiral decoration from Park Lane cemetery, Croydon (no scale was provided in the original version of this figure; photograph courtesy of Wessex Archaeology).

this "distinctly Germanic" material expression was "bursting with dynamic force and expansion”. Beyond its location in Germania, this 'dynamism' is Inker's sole basis for claiming that the Saxon Relief Style conveyed a 'Germanic' cultural ethos.

Do we have any categorical evidence for the cultural beliefs that the users of the materials bearing these styles are purported to share? There is growing dissatisfaction with 'Germanic' as an analytical category, particularly when used to describe a putative ideological system that unified the languages, behaviour, cultural products, cosmologies, political formations and social structures of the diverse inhabitants of Germania Magna in Late Antiquity. Critiques have been published in relation to the full range of material to which the concept has been applied, ranging from historiography, literature and linguistics, to legal codes and material culture (Goffart 1995, 2002; Barnwell 2000; Halsall 2007; von Rummel 2007, 2013; Jarnut 2012; Goering in press). There is almost no evidence that the disparate social groups found along the Baltic and the North Sea coasts, in Germany, across the Danube and in Scandinavia shared a conscious identity in Late Antiquity (Pohl 2004: 50-51; Halsall 2007). Some modern historians label these groups Germani, but as von Rummel (2013) notes, it is surely ironic that modern scholars so frequently accept the artificial categories that Roman ethnographers imposed upon the subjects of their works for the purpose of domination. The inhabitants of Germania Magna communicated far more frequently with the inhabitants of the Roman Empire than with other groups in the region, or their putative 'ethnic comrades' farther north (Lee 1993). This should hardly be surprising, given that many of the major players in politics in the region lived on the Roman frontiers (Shaw 2002: 50-54).

We lack evidence for whether pagan myths took the same form in the fourth to sixth centuries as those recorded in the later High Middle Ages. In some cases, we know that they did not. Shaw (2002), for example, has demonstrated the improbability that the temporally separated deities, Wodan and Óðinn, can be associated with one another beyond etymology, or that Wodan was worshipped in Anglo-Saxon England prior to the eighth century. This poses

(C) Antiquity Publications Ltd, 2019 
difficulties for those who would interpret figural depictions on bracteates (Figure 7) as the 'breath of Odin' (Pesch 2017). Hawkes (1997) has highlighted the considerable empirical issues that face the scholar attempting to link material as chronologically distant as Tacitus' Germania and the Prose Edda of Snorri Sturlusson. Arguments concerning Style I and its putative mythological content are based upon dubious retrospective projection from later source material. Høilund Nielsen's (2012) recent overview shows that scholarship on early medieval animal art style is beginning to recognise this problem, although she seems reluctant to abandon the notion that these styles could convey gods and myths, and instead simply asserts that their names and stories are unknowable.

Even if we accept that the use of this material culture in North-western Europe evidences the contribution of identity boundaries, it remains impossible to infer which facets of social identity were being expressed. von Rummel (2013) highlights that an artificial dichotomy

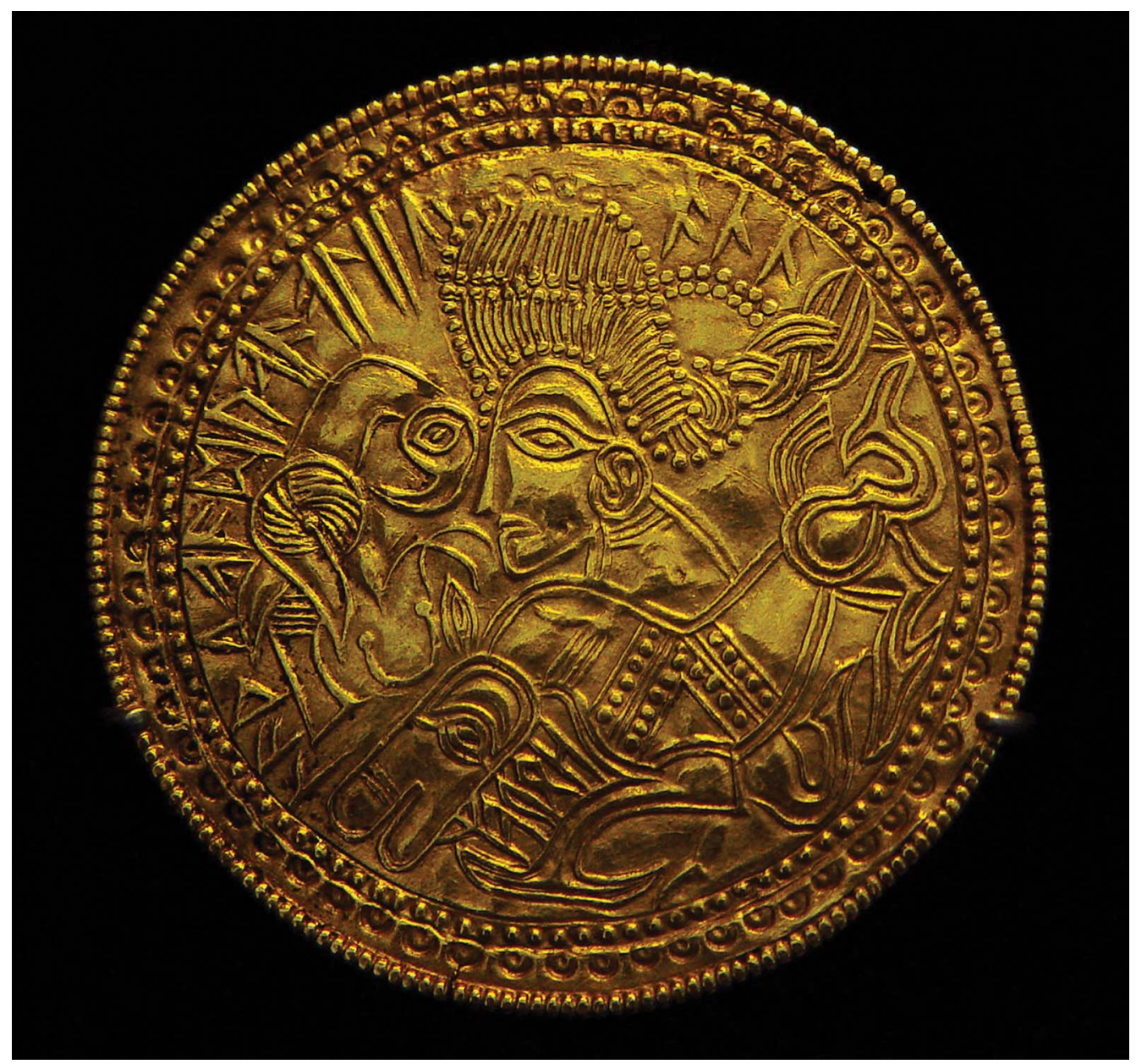

Figure 7. Bracteate from Funen, Denmark (no scale was provided in the original version of this figure; photograph by WikipedialBloodofox, distributed under a CC-BY 2.0 licence).

(C) Antiquity Publications Ltd, 2019 
between 'Germanic' and 'Roman' modes of dress and burial continues to drive the interpretation of Late Roman and early medieval mortuary evidence. Roman burial is often defined merely by an absence of putatively 'Germanic' grave goods (e.g. Bierbrauer 2003; Riemer 2003; Carver et al. 2009: 105; for criticism, see von Rummel 2013). In Britain, this dichotomy is exacerbated by an artificial chronological divide caused by dating methodology (for a critique of this dichotomy, see Harland 2017a: 129-37). Due to the early fifth-century collapse of the coin supply to Britain and difficulties with precise radiocarbon dating of fifth-century contexts, the date for the introduction of Style I is based upon the integration of typological phases of various artefacts with a series of closed-context coin-dated continental burials. Yet Gerrard (2015) has found that many cemeteries in Britain usually identified as pre-dating AD 400-based on an absence of 'Germanic' grave goods and coin dating-may, in fact, on the basis of radiocarbon analyses, date to the fifth or sixth centuries. Rau (2010: 31-123) places Style I's introduction into Scandinavia approximately 25 years earlier than previously believed, at $c$. AD 455-465. The chronological gap between Late Roman and 'early Anglo-Saxon' material is narrowing and, in all likelihood, it is an interpretative illusion.

This has substantial implications. Hills and Lucy (2013), for example, in their final volume on Spong Hill, usefully move away from interpretations that rely on an inflexible chronological binary to date the Adventus Saxonum. Yet they propose that the cemetery evidences a 'Germanic' cultural system, which was ideologically distinct from the 'Romanness' that preceded it. Indeed, Hills and Lucy (2013: 330) argue that the sixth century may have been a period of 'ethnogenesis' made physically manifest in the selection of components of an "identity-bearing assemblage developed within England"; they further suggest that it is therefore reasonable to categorise the region's identity as 'Anglian'. Their basis for this is, for example, interpretations of the artefacts from this region made by scholars such as Martin (Hills \& Lucy 2013: 303-307).

It is unclear why the cultural system described by Hills and Lucy (2013) needs to be so distinct (see Effros 2015). The only probable unifying factor shared by the disparate Late Roman peoples of Germania Magna was their involvement in the politics and military of the Roman Empire. Halsall (pers. comm.) has therefore claimed that Style I and related styles became popular in North-western Europe-following the Western Empire's political demise in the fifth century - due to their transformation of Late Roman motifs that represented a stable centre and periphery into motifs of 'undecideability'. Such an interpretative leap derives from empirically verifiable aspects of these styles, rather than speculative assertions about cosmology. Adams (2015), for example, has interpreted these animal art styles as originating specifically in Late Roman hunting imagery. It is therefore difficult to assume that Style I indicates a firm chronological and cultural boundary, representing the arrival of a 'Germanic ideology'.

\section{'Folk' costume? The peplos dress}

Another common assertion is that early Anglo-Saxon grave goods represent traditional folk costume (Tracht) that conveyed an essential 'Germanic character', beneath which were subsumed specific group identities (e.g. Hines 1998: 280-81; Ravn 2003: 127; Owen-Crocker 2004: 42-54; Walton Rogers 2007). This assertion is based upon these grave goods being worn on a garment known as a peplos dress. The peplos-a tubular cloth fastened at the 
shoulders by a pair of brooches-is attested in numerous ancient societies. Employing detailed studies of the age, sex and social position of those who wore the peplos in early Anglo-Saxon England, Martin (2015) has argued that this garment was an ideological expression. Martin's (2015: 192) assertion, however, that the ideology being expressed represented a coherent 'Germanic' cultural package is based entirely on the presence of this costume in "classical sculpture of Germanic dress". For Martin (2015: 192), this proves the "authenticity and practicality" of this mode of dress, implicitly suggesting its traditionally 'Germanic' nature. The peplos dress features in second-century AD depictions of female captives from Germania, such as on the Column of Marcus Aurelius in Rome, and is attested in later archaeological contexts from, for example, eighth-century Scandinavia (Owen-Crocker 2004: 43).

How does this reflect the authentically Germanic nature of such costume, rather than it representing a simple and effective method of garment fastening? Recent research bases its assertions about the putatively Germanic nature of fifth-century peplos dress on earlier continental scholarship (e.g. Böhme 1974, 1981; for a critique, see Halsall 2011). Effros (2004) has observed that this scholarship relies upon an assumed passivity of the women wearing such costume, and bearing cultural connotations transmitted to them in their putative role as 'soldiers' wives'. While Martin (2015) makes a convincing case for the active role of women in the formation of Anglian identity through negotiation of the complex relationships between adornment and stage in the life cycle, the 'Germanic' aspects of Martin's argument remain reliant upon this assumption. Another cause for doubt is that the peplos was known in northern Gaul until the third century AD. Depictions of the garment then vanished for three centuries, before re-appearing simultaneously in northern Gaul and Germania in the early fifth century (Walton Rogers 2007: 150-51). It is thus absurd to argue that the peplos functioned as a component of 'Germanic' Tracht. On these grounds, the same could be said for them forming a component of traditional, 'authentic' Roman dress.

While it is true that the peplos is not widely depicted in Roman art, von Rummel (2007: 277) points out that to thereby regard it as Germanic is to argue based on an absence of evidence-an argument reliant on heavily context-specific artistic and documentary source material. Due to the predominance of the cremation funerary rite, knowledge of how commonly encountered fibulae were used in costume in both within the Empire and Barbaricum beyond is lacking. Nevertheless, repeated studies have found that the peplos was worn as frequently in parts of the Empire, such as northern Gaul, as it was in Barbaricum (Martin 1995: 678; von Rummel 2007: 281-83).

Appeals to 'authenticity' will not do. Alternative explanations for the peplos are available. Halsall (2011), for example, interprets the presence of the peplos in Gaul as representative of a growth in the popularity of female bodily adornment in response to a decline in the use of other types of funerary display. Halsall $(1995,2004,2007,2009)$ relates this practice, which in northern Gaul used a distinctly provincial Roman type of brooch, to the emergence of furnished inhumation burial, which was itself, he argues, a response to increased social insecurity. von Rummel (2007) has likewise made a similar argument for 'Vandal' material from North Africa. A potential objection could be raised here that the brooches used to fasten the peplos dress in Britain were definitely an import, demonstrating close ties to Germania. There is, moreover, a substantial concentration of paired shoulder brooches in northern

(C) Antiquity Publications Ltd, 2019 
Barbaricum —of the so-called 'Sîntana de Mureș/Černjachov culture'. Unlike von Rummel's North African (or Halsall's Gallic) material, many components in Anglo-Saxon burial costume can be linked confidently to such material in continental Northern Europe (Böhme 1974; Hines 1984). Eger (2011), meanwhile has attempted to refute von Rummel's assertions regarding the peplos dress. Eger (2011), however, does so solely based on Böhme's (1974) explanation of the three-century absence of the Gallic rite, and on allegations of a lack of research attention to the Danube. Halsall (2009) has dismantled Böhme's assertions, and von Rummel (2007: 279-82) does discuss the Danube; but even if he had not, this is hardly a satisfactory basis for establishing the existence of a continuous 'Germanic tradition'. Eger's challenge to (2011: 225-26) von Rummel simply follows Böhme's assertion that a 'resurrection' of the Gallic rite took place in the fifth century-which is pure speculation. Even if it were not, the only way that this would demonstrate a continuous, widespread 'Germanic' tradition would be if we assumed that trans-Danubian people- those who used the Sîntana de Mureş/Černjachov Culture, for example—could likewise be subsumed under a pan-Germanic ethos. This is not a priori proof that there existed an 'authentic' Germanic tradition with an unbroken history. The only way to argue for such an alternative tradition is by linking this material and its distribution to a wider, contemporaneously perceived panGermanic ethos, with no current empirical basis. Moreover, the group usually associated with the Sîntana de Mureș/Černjachov Culture-the Goths—-were never considered Germani by Roman ethnographers (Kulikowski 2007: 46-47).

\section{Conclusions}

Ethnic identity cannot be demonstrated through purely archaeological means (Brather 2004; Halsall 2011). In the fifth-century AD burial costume of lowland Britain, we find prima facie evidence for neither ethnic expression nor the cultural and social infrastructure that would produce it. The present article has necessarily focused on dismantling current approaches, as it is far from simple to force the reconsideration of dominant disciplinary paradigms (for further discussion, see Harland 2017b). Yet alternative interpretative frameworks are available. It is possible, for example, that putatively 'Germanic' mortuary evidence reflects a wider pattern of provincial militarisation-with concomitant shifts in the construction of gender through mortuary costume- that took place across the Empire in the fifth century (Halsall 2004; von Rummel 2007). I have recently argued (Harland 2017a) that post-Roman elites in Britain grappled with 'Romanness' in diverse ways, some of which deviated from expected civic norms. I have proposed that the contemporaneous commentator Gildas (De Excidio; Mommsen 1898) may have alluded to precisely such concerns, using language that admitted that although he did not consider the stylistic references that these elites drew upon to be legitimately 'Roman', those elites themselves may have disagreed. The question we should possibly be asking is not whether a 'Germanic' ideology was imported into Britain, but rather, why Britain, while undergoing a similar transformation of ideological norms to that experienced on the continent, made use of material from Barbaricum. Given Britain's dramatic dislocation from the Roman Empire's logistical structures in the early fifth century (Gerrard 2013), it is hardly surprising that people in Britain turned to material from across the North Sea, where power was framed by the same expectations as

(C) Antiquity Publications Ltd, 2019 
within the Empire (Halsall 2007; Harland 2017b). This hypothesis will be explored in a forthcoming monograph (Harland in press). Although much of our understanding proceeds in interpretative leaps based on what can be empirically demonstrated, by avoiding ethnic narratives, new interpretative questions abound.

Perhaps it is time to cease interpreting the fifth-century mortuary material culture of lowland Britain through a 'Germanic' tradition or myth. We are witnessing an alarming growth of ethno-nationalism, and the popularity of such interpretations should prompt reflection, especially given the origins of Germanische Altertumskunde in an ethno-nationalist setting that produced some of the worst crimes in modern history (Effros 2012; Wood 2013). Scholars of early Anglo-Saxon archaeology acknowledge this troublesome past and have devoted considerable effort to opposing the abuse of archaeological material to such abhorrent ends (Williams 2007). Regardless, I fear that until we abandon the baseless notion that the diverse peoples who migrated to Britain in the fourth to sixth centuries shared a coherent, 'Germanic' cultural ethos, we will continue—even unwittingly— to provide ammunition to those who would use such interpretations to justify oppression in the present.

\section{Acknowledgements}

I am grateful to Guy Halsall for supervising the $\mathrm{PhD}$ on which this article is based. Completed in York in 2017, it was funded by the AHRC under grant 1362784. James Gerrard, Kat Fliegel, Lucy Sackville and Andrew Welton have offered helpful remarks, as have the anonymous reviewers. I am also grateful to the peer reviewers and editors for suggestions that have considerably improved the quality and clarity of the manuscript. A version of this article was delivered at the Leeds International Medieval Congress in 2018, and I wish to thank Richard Flower, Robin Whelan and Adrastos Omissi for inviting me to deliver that paper. I am also grateful to the Deutsche Forschungsgmeinschaft Center for Advanced Studies 2496, 'Migration and Mobility in Late Antiquity and the Early Middle Ages', in Tübingen, for hosting me as a fellow in the period during which this article was corrected.

\section{References}

Adams, N. 2015. Between myth and reality: hunter and prey in early Anglo-Saxon Art, in M.D.J. Bintley \& T.J. Williams (ed.) Representing beasts in early medieval England and Scandinavia: 13-52. Woodbridge: Boydell \& Brewer.

BARNWELL, P. 2000. Emperors, jurists and kings: law and custom in the Late Roman and early medieval West. Past \& Present 168: 6-29. https://doi.org/10.1093/past/168.1.6

BeHR, C. 2000. The origins of kingship in early medieval Kent. Early Medieval Europe 9: 25-52. https://doi.org/10.1111/1468-0254.00058

- 2007. Using bracteates as evidence for long distance contacts, in A.L. Harris (ed.) Incipient globalization? Long distance contacts in the sixth century (British Archaeological Reports International series 1644): 15-25. Oxford: Archaeopress.

Behr, C. \& T. Pestell. 2014. The bracteate hoard from Binham—an early Anglo-Saxon central place? Medieval Archaeology 58: 44-77. https://doi.org/10.1179/0076609714Z. 00000000031

Bierbrauer, V. 2003. Romanen, in H. Beck, D. Geuenich \& H. Steuer (ed.)

Rindenboot-Rzucewo-Kultur (Reallexicon der germanischen Altertumskunde 25): 210-42. Berlin: De Gruyter.

Böнme, H.W. 1974. Germanische Grabfunde des 4. bis 5. Jahrhunderts. Munich: Beck.

- 1981. Das Ende der Römerherrschaft in Britannien und die Angelsächsische Besiedlung Englands im 5. Jahrhundert. Jahrbuch des Römisch-Germanischen Zentralmuseums, Mainz 33: 469-574.

Brather, S. 2004. Ethnische Interpretationen in der Frühegeschichtlichen Archäologie. Berlin: De Gruyter.

BRUBAKer, R. 2004. Ethnicity without groups. Cambridge (MA): Harvard University Press. https://doi.org/10.1017/CBO9780511489235. 004

(C) Antiquity Publications Ltd, 2019 
Carver, M., C. Hills \& J. Scheschkewitz. 2009. Wasperton: a Roman, British and Anglo-Saxon community in central England. Woodbridge: Boydell.

Colgrave, B. \& R.A.B. Mynors. 1969. Bede's ecclesiastical history of the English people. Oxford: Oxford University Press.

Dickinson, T.M. 2002. Translating animal art: Salin's Style I and Anglo-Saxon cast saucer brooches. Hikuin 29: 163-86.

Effros, B. 2004. Dressing conservatively: women's brooches as markers of ethnic identity?, in L. Brubaker \& J.M.H. Smith (ed.) Gender in the early medieval world: East and West, 300-900: 165-84. Cambridge: Cambridge University Press.

- 2012. Uncovering the Germanic past. Oxford: Oxford University Press.

- 2015. Review of Catherine Hills \& Sam Lucy. Spong Hill IX: chronology and synthesis. 2013. Antiquity 89: 1260-61.

https://doi.org/10.15184/aqy.2015.122

Eger, C. 2011. Kleidung und Grabausstattung barbarischer Eliten im 5. Jahrhundert: Gedanken zu Philipp von Rummels 'Habitus barbarus'. Germania 89: 215-30.

Gerrard, J. 2013. The ruin of Roman Britain: an archaeological perspective. Cambridge: Cambridge University Press. https://doi.org/10.1017/CBO9781139839129

- 2015. Synthesis, chronology, and 'Late Roman' cemeteries in Britain. American Journal of Archaeology 119: 565-72.

https://doi.org/10.3764/aja.119.4.0565

Gillett, A. 2002. On barbarian identity: critical approaches to ethnicity in the early Middle Ages. Turnhout: Brepols.

https://doi.org/10.1484/M.SEM-EB.6. 09070802050003050101060809

Goering, N. In press. (Proto-)Germanic alliterative verse: linguistic limits on a cultural phenomenon, in J.M. Harland \& M. Friedrich (ed.) Interrogating the 'Germanic': a category and its use in Late Antiquity and the early Middle Ages. Berlin: De Gruyter.

Goffart, W. 1995. Two notes on Germanic antiquity today. Traditio 50: 9-30. https://doi.org/10.1017/S0362152900013143

- 2002. Does the distant past impinge on the Invasion Age Germans?, in A. Gillett (ed.) On barbarian identity: critical approaches to ethnicity in the early Middle Ages: 21-38. Turnhout: Brepols.

HAKENBECK, S.E. 2011. Local, regional and ethnic identities in early medieval cemeteries in Bavaria (Contributi di Archaeologia Medievale 5). Florence: All'Insegna del Giglio.

Halsall, G. 1995. Settlement and social organization: the Merovingian region of Metz. Cambridge: Cambridge University Press

- 2004. Gender and the end of empire. Journal of Medieval and Early Modern Studies 34: 17-39. https://doi.org/10.1215/10829636-34-1-17

- 2007. Barbarian migrations and the Roman West. Cambridge: Cambridge University Press.

- 2009. Commentary two: careful with that axe, Eugenius, in G. Halsall (ed.) Cemeteries and society in Merovingian Gaul: 131-67. Leiden: Brill. https://doi.org/10.1163/ej.9789004179998.i422.35

- 2011. Ethnicity and early medieval cemeteries. Arquelogia y Territorio Medieval 18: 15-27.

Härke, H. 1990. 'Warrior graves'? The background of the Anglo-Saxon weapon burial rite. Past \& Present 126: 22-43. https://doi.org/10.1093/past/126.1.22

HarLand, J.M. 2017a. Rethinking ethnicity and 'otherness' in early Anglo-Saxon England. Medieval Worlds 5: 113-42.

https://doi.org/10.1553/ medievalworlds_no5_2017s113

- 2017b. Deconstructing Anglo-Saxon archaeology: a critical enquiry into the study of ethnicity in lowland Britain in late antiquity (c. 350-600). Unpublished PhD dissertation, University of York.

- In press. Ethnic identity in early Anglo-Saxon archaeology. Amsterdam: Amsterdam University Press.

Haseloff, G. 1974. Salin's Style I. Medieval Archaeology 18: 1-15. https://doi.org/10.1080/00766097.1974. 11735362

- 1981. Die germanische Tierornamentik der Völkerwanderungszeit. Studien zu Salins Stil I. Berlin: De Gruyter.

Hawkes, J. 1997. Symbolic lives: the visual evidence, in J. Hines (ed.) The Anglo-Saxons from the migration period to the eighth century: an ethnographic perspective: 311-38. Woodbridge: Boydell. 
Hedeager, L. 2000. Migration Period Europe: the formation of a political mentality, in J.L. Nelson \& F. Theuws (ed.) Rituals of power: from Late Antiquity to the Early Middle Ages: 15-58. Leiden: Brill.

- 2011. Iron Age myth and materiality: an archaeology of Scandinavia, AD 400-1100. London: Routledge.

Hills, C. 1979. The archaeology of Anglo-Saxon England in the pagan period: a review. Anglo-Saxon England 8: 297-329. https://doi.org/10.1017/S0263675100003112

- 2003. The origins of the English. London: Duckworth.

- 2015. The Anglo-Saxon migration: an archaeological case study of disruption, in B. J. Baker \& T. Tsuda (ed.) Migrations and disruptions: toward a unifying theory of ancient and contemporary migrations: 33-51. Gainesville: University of Florida Press. https://doi.org/10.5744/florida/ 9780813060804.001 .0001

Hills, C. \& S. Lucy. 2013. Spong Hill IX: chronology and synthesis. Cambridge: McDonald Institute for Archaeological Research.

Hines, J. 1984. The Scandinavian character of Anglian England in the pre-Viking Period (British Archaeological Reports British series 124). Oxford: British Archaeological Reports.

- 1998. A new corpus of great square-headed brooches. Woodbridge: Boydell.

Høilund Nielsen, K. 2012. Germanic animal art and symbolism, in H. Beck, D. Geuenich \& H. Steuer (ed.) AltertumskundeAltertumswissenschaft_Kulturwissenschaft: 589632. Berlin: De Gruyter.

Inker, P. 2006. The Saxon Relief Style (British Archaeological Reports British series 410). Oxford: Archaeopress.

Jarnut, J. 2012. Zum 'Germanen'-Begriff der Historiker, in H. Beck, D. Geuenich \& H. Steuer (ed.) Altertumskunde-AltertumswissenschaftKulturwissenschaft: 391-400. Berlin: De Gruyter.

Kulikowski, M. 2007. Rome's Gothic wars. Cambridge: Cambridge University Press.

LEE, A.D. 1993. Information and frontiers: Roman foreign relations in Late Antiquity. Cambridge: Cambridge University Press. https://doi.org/10.1017/CBO9780511470622

Leeds, E.T. 1912. The distribution of the Anglo-Saxon saucer brooch in relation to the
Battle of Bedford, AD 571. Archaeologia 63: 159202. https://doi.org/10.1017/S0261340900011620

LuCY, S. 1998. The early Anglo-Saxon cemeteries of East Yorkshire: an analysis and reinterpretation (British Archaeological Reports British series 272). Oxford: Archaeopress.

- 2000. The Anglo-Saxon way of death. Stroud: Sutton.

- 2002. Burial practice in early medieval eastern Britain: constructing local identities, deconstructing ethnicity, in S. Lucy \& A. Reynolds (ed.) Burial in early medieval England and Wales: 72-81. London: Council for British Archaeology.

Martin, M. 1995. Tradition und Wandel der fibelgeschmückten frühmittelalterlichen Frauenkleidung. Jahrbuch des RömischGermanischen Zentralmuseums Mainz 38: 62880.

Martin, T.F. 2015. The cruciform brooch and Anglo-Saxon England. Woodbridge: Boydell \& Brewer.

Mommsen, T. 1898. Gildas: De excidio et conquestu Britanniae (Monumenta Germaniae Historica: Auctores Antiquissimi 13). Berlin: Weidmann.

Owen-Crocker, G. 2004. Dress in Anglo-Saxon England. Woodbridge: Boydell.

PADER, E.-J. 1982. Symbolism, social relations and the interpretation of mortuary remains (British Archaeological Reports International series 130). Oxford: Archaeopress.

Pesch, A. 2017. Facing faces: the head motif in Migration-Period archaeology. Medieval Archaeology 61: 41-68. https://doi.org/10.1080/00766097.2017. 1296609

Poнl, W. 2004. Die Germanen. Munich: Oldenbourg. https://doi.org/10.1524/9783486701623

Ravn, M. 2003. Death ritual and Germanic social structure (c. AD 200-600) (British Archaeological Reports International series 1164). Oxford: Archaeopress.

Rau, A. 2010. Nydam Mose 1-2: Die personengebundenen Gegenstände. Aarhus: Aarhus University Press.

Riemer, E. 2003. Romanische Grabfunde des 5-8. Jahrhunderts in Italien (Internationale Archäologie 57). Rahden: VML.

SHAw, P.A. 2002. Uses of Wodan: the development of his cult and of medieval literary responses to it.

(C) Antiquity Publications Ltd, 2019 
Unpublished $\mathrm{PhD}$ dissertation, University of Leeds.

University of Sheffield. 2018. Remains of Anglo-Saxon cemetery discovered, 27 November 2018. Available at: https://www.sheffield.ac.uk/news/nr/remainsanglo-saxon-cemetery-discovered-1.818242 (accessed 29 March 2019).

von Rummel, P. 2007. Habitus Barbarus. Kleidung und Repräsentation spätantiker Eliten im 4. und 5. Jahrbundert. Berlin: De Gruyter.

- 2013. The fading power of images: Romans, barbarians, and the uses of a dichotomy in early medieval archaeology, in W. Pohl \& G. Heydemann (ed.) Post-Roman transitions: Christian and barbarian identities in the early medieval West: 365-406. Turnhout: Brepols.

Walton Rogers, P. 2007. Cloth and clothing in early Anglo-Saxon England, AD 450-700. York: Council for British Archaeology.

Webster, L. 2009. Style: influences, chronology and meaning, in H. Hamerow, D. Hinton \& S. Crawford (ed.) The Oxford handbook of
Anglo-Saxon archaeology: 460-500. Oxford: Oxford University Press.

Wenskus, R. 1961 Stammesbildung und Verfassung: Das Werden der frühmittelalterlichen gentes. Cologne: Böhlau.

Williams, H. 2007. 'Burnt Germans', Alemannic graves and the origins of Anglo-Saxon archaeology, in S. Burmeister, H. Derks \& J. von Richthofen (ed.) Zweiundvierzig. Festschrift für Michael Gebühr zum 65. Geburtstag. 229-38. Rahden: Leidorf.

WIMMER, A. 2013. Ethnic boundary making: institutions, power, networks. Oxford: Oxford University Press. https://doi.org/10.1093/acprof:oso/ 9780199927371.001 .0001

Wolfram, H. 1979. Geschichte der Goten, von den Anfängen bis zur Mitte des sechsten Jahrhunderts: Entwurf einer historischen Ethnographie. Munich: Beck.

Wood, I. 2013. The modern origins of the Early Middle Ages. Oxford: Oxford University Press. https://doi.org/10.1093/acprof:oso/ 9780199650484.001 .0001

Received: 7 July 2018; Revised: 5 December 2018; Accepted: 7 January 2019 